\title{
Human Divine Communication as a Paradigm for Power: Al-Tha'labỉ's Presentation of Q. 38:24 and Q. 38:34
}

\author{
Marianna Klar, SOAS, University of London
}

Verses 24 to 25 of sura 38 ( $S \bar{a} d)$ of the Qur'an tell us David realized that We had been testing him, so he asked forgiveness of his Lord, fell down on his knees, and repented: We forgave him [his misdeed]. His reward will be nearness to Us, a good place to return to ${ }^{1}$ verses 34 to 35 of the same sura tell us We certainly tested Solomon, reducing him to a mere skeleton on the throne. He turned to Us and prayed: 'Lord, forgive me! Grant me such power as no one after me will have - You are the Most Generous Provider', then, at verse 40, His reward will be nearness to Us, a good place to return to. Both passages mention a God-given trial, the repentance of a prophet, and the reward of nearness to Us, a good place to return to. Yet the medieval Muslim historiographical tradition presents very different narratives, and very different personalities, in elucidation of these two episodes. The two questions that will be addressed in this essay are: restricting our focus to communication patterns and how God is presented in the narrative, how do these two narratives differ? And, secondly, can we find reasons in the text of the Qur'anic passages themselves for why they differ?

Muslim historiography constructs a (strictly non-canonical) salvation history, built out of a series of anecdotes regarding the pre-Islamic prophets, some independently authored and some re-worded by the compiler of the history, all arranged in a loosely chronological pattern. ${ }^{2}$ Many of these anecdotes posit contradictory versions of events, and this results in a richly nuanced text but one which can, and should, sometimes be read as a coherent whole. Al-Tha'labī's (d. 427/1035) eleventh century historiographical text is arguably the most comprehensive and most influential text of

\footnotetext{
${ }^{1}$ Translations of the Qur'an are taken from M.A.S. Abdel Haleem (trans.), The Qur'an: A New Translation, Oxford World Classics, Oxford-New York: Oxford University Press, 2005.

${ }^{2}$ Comprehensive information on the pre-Islamic prophets can be found in the Qisas al-anbiyā' of 'Umāra b. Wathīma (d. 289/902), the Ta'rīkh al-umam wa'l-muluk of al-Tabarī (d. 310/923), the Qiṣas al-anbiyā' of al-Kisā' $\overline{1}$ (fl. $6^{\text {th }} / 12^{\text {th }}$ century), the Tärīkh al-kabīr of Ibn al-Athīr (d. 630/1233), the al-
} 
its genre regarding the pre-Islamic prophets, ${ }^{3}$ and in this paper I wish to concentrate on the discourse patterns between God and His prophet within the David and the Solomon narratives, and on the resultant indications of the nature of the power relationships between God and David, God and Solomon, within this text. There is some variegation in the pattern of God's discourse with the twenty four pre-Islamic prophets that are mentioned within the Qur'anic narrative, from direct speech to communication via angelic messenger to no reported dialogue at all (Q. 42:51 gives a brief description of this communication process), ${ }^{4}$ but generally speaking the historiographical tradition, which expands and reworks the Qur'anic passages into its chronologically arranged salvation history, alludes to an extremely interactive relationship between God and prophet.

The David narrative is no exception to this pattern. The prophet's story is littered with examples of his dialogue with God, which for the most part exhibit how David turns to God with his worries and his concerns, and the fact that God responds to His prophet with great openness. If we look at every occasion where the two have dialogue, we find David asking God why his powers wane after he is tempted, and God conversing with him on this issue, ${ }^{5}$ God telling David, in a dream, to have a guilty man executed in order to increase his sovereignty among his people; ${ }^{6}$ David

Bidāya wa'l-nihāya of Ibn Kathīr (d. 774/1373), and the Tārīkh madīnat Dimashq of Ibn 'Asākir (d. 571/1176). The works of al-Ṭabarī and al-Kisā' $\overline{1}$ are available in English translation.

${ }^{3}$ For more information on al-Tha'labī's collection of tales of the prophets see B.M. Hauglid, AlTha 'labī's Qișas al-Anbiyā': Analysis of the Text, Jewish and Christian Elements, Islamization, and Prefiguration of the Prophethood of Muhammad, Unpublished dissertation, Ann Arbor: UMI, 1998, Marianna Klar, 'Stories of the Prophets', in A. Rippin (ed.), Blackwell Companion to the Qur'an, Oxford: Blackwell, 2006, pp. 338-49 and idem, Interpreting al-Tha 'labì's Tales of the Prophets: Temptation, Responsibility and Loss, RoutledgeCurzon, 2009, T. Nagel, Die Qiṣaș al-Anbiyā': Ein Beitrag zur Arabischen Literaturgeschichte, Unpublished dissertation, Bonn: Rheinische FriedrichWilhelms-Universität, 1967, pp. 80-102; R. Tottoli, Biblical Prophets in the Qur'ān and Muslim Literature, Curzon Studies in the Qur'an, Richmond: Curzon Press, 2002, pp. 146-51. For an in-depth discussion of al-Tha'labī's life and works see W.A. Saleh, The Formation of the Classical Tafsīr Tradition: The Qur'ān Commentary of al-Tha 'labī (d. 427/1035), Texts and Studies on the Qur'ān, vol. 1, Leiden-Boston: Brill, 2004, pp. 25-65.

${ }^{4}$ It is not granted to any mortal that God should speak to him except through revelation or from behind a veil, or by sending a messenger to reveal by His command what He will: He is exalted and wise.

${ }^{5}$ See Abū Ishāa Aḥmad b. Muhammad b. Ibrāhīm al-Nīsābūrī, al-ma 'rūf bi'l-Tha 'labī, Qiṣaṣ alanbiyā', al-musammā 'Arā' is al-majālis, $4^{\text {th }}$ edn, Beirut: Dār al-Kutub al-'Ilmiyya, 1985, p. 276 citing an anonymous account (cf. W.M. Brinner (trans. and annot.), 'Arā'is al-majālis fi qișaș al-anbiyā', or "Lives of the Prophets" as recounted by Abū Ishāq Aḥmad ibn Muhammad ibn Ibrāhìm al-Tha 'labī, Studies in Arabic Literature: Supplements to the Journal of Arabic Literature, vol. 24, LeidenBoston-Köln: Brill, 2002, p. 463).

${ }^{6}$ See al-Tha'labī, Qiṣaș al-anbiyā', p. 278 citing Ibn 'Abbās (cf. Brinner, 'Arā'is al-majālis, pp. 4667). 
asking God about the merits of his forefathers, and God conversing with him on this issue, ${ }^{7}$ David asking God to make him responsible for his own soul, and God conversing with him on this issue; ${ }^{8}$ David asking God to forgive him his weakness over Bathsheba; ${ }^{9}$ David addressing God at length in his repentance, God responding that David should act to address his perceived difficulties, David declaring his sin, and God declaring His forgiveness; ${ }^{10}$ God again declaring His forgiveness, but David wishing for Uriah's forgiveness, so God telling him to go to Uriah's tomb where $\mathrm{He}$ will cause him to hear David's plea; ${ }^{11}$ God telling David to inform Uriah that he has married Bathsheba; ${ }^{12}$ God again telling David He has forgiven him his slip, but David again querying how God can forgive him when Uriah has not, that is until God explains to David how He will recompense Uriah on Judgement Day, and David accepting the reality of God's forgiveness; ${ }^{13}$ David speaking to God of his transgression, God's mercy, and the treatment for his condition; ${ }^{14}$ David asking God to forgive other sinners that He might perhaps forgive David alongside them; ${ }^{15}$ David asking whether God has forgiven him, to which God replies 'Yes', so David asks for a reminder of his sin, and God responds by tattooing it onto his right hand. ${ }^{16}$

Contrast this impression with the situation that transpires in al-Tha'labī's Solomon narrative. There, direct conversation with God is scant: Solomon asks God to forgive him for the tears of David over his transgression; ${ }^{17}$ God speaks of His gifts to

\footnotetext{
${ }^{7}$ See al-Tha'labī, Qiṣaṣ al-anbiyā', p. 279 citing al-Suddī, al-Kalbī and Muqātil (cf. Brinner, 'Arā'is al-majālis, pp. 468-9).

${ }^{8}$ See al-Tha'labī, Qiṣaș al-anbiyā', p. 280 citing Abū Bakr b. Muḥammad b. 'Umar al-Warrāq (cf. Brinner, 'Arā'is al-majālis, p. 470).

${ }^{9}$ See al-Tha 'labī, Qișaș al-anbiyā', p. 282 citing a Hadīth (cf. Brinner, 'Arā'is al-majālis, p. 473).

${ }^{10}$ See al-Tha 'labī, Qișaș al-anbiyā', pp. 283-4 citing Ka‘b al-Aḥār and Wahb b. Munabbih (cf. Brinner, 'Arā'is al-majālis, pp. 474-5).

${ }^{11}$ See al-Tha'labī, Qiṣaṣ al-anbiyā', p. 284 citing Wahb b. Munabbih (cf. Brinner, 'Arā'is al-majālis, pp. 475-6).

${ }^{12}$ See al-Tha 'labī, Qiṣaṣ al-anbiyā', p. 284 citing Wahb b. Munabbih (cf. Brinner, 'Arā'is al-majālis, p. 476).

${ }^{13}$ See al-Tha 'labī, Qiṣaṣ al-anbiyā', p. 284 citing Wahb b. Munabbih (cf. Brinner, 'Arā'is al-majālis, p. 476).

${ }^{14}$ See al-Tha 'labī, Qiṣaṣ al-anbiyā', p. 285 citing al-Ḥasan b. 'Abd Allāh al-Qurashī (cf. Brinner, 'Arā'is al-majālis, p. 477).

${ }^{15}$ See al-Tha'labī, Qișaș al-anbiyā', p. 286 citing Wahb b. Munabbih (cf. Brinner, 'Arā'is al-majālis, p. 479).

${ }^{16}$ See al-Tha 'labī, Qiṣaṣ al-anbiyā', p. 286 citing Wahb b. Munabbih (cf. Brinner, 'Arā'is al-majālis, p. 479).

${ }^{17}$ See al-Tha 'labī, Qișaș al-anbiyā', p. 285 citing Wahb b. Munabbih (cf. Brinner, 'Arā'is al-majālis, p. 478 , for a quite different rendition of this passage).
} 
Solomon; ${ }^{18}$ Solomon speaks at the sacrifice on the Rock; $;{ }^{19}$ Solomon addresses God after the discovery of the idol in his palace; ${ }^{20}$ Solomon asks God to conceal his death from the jinn. ${ }^{21}$ What is immediately striking about this list is that although it includes a few instances where Solomon addresses God, or vice versa, there is no episode of true dialogue between the pair.

This is not however to imply that God does not respond to Solomon's requests: when the prophet prays to God that the Queen of Sheba's throne be brought to him, God immediately responds; ${ }^{22}$ when the tree worm and the white worm ask that their source of sustenance be trees and fruits respectively, the prophet says that they shall have it, we can only assume in full confidence that God will endorse this promise. ${ }^{23}$ The prophet moreover communicates with God by means of the use of sacrifice. Thus sacrifice is used to ascertain whether or not God has sanctioned his plea that the mosque he builds at the Temple should have special cleansing powers: a bolt of flame does descend from heaven and consume the sacrifice, thereby presumably indicating God's approval. ${ }^{24}$ In another anecdote included within the Solomon narrative, the prophet uses sacrifice to express his regret at the perceived sin of missing a prayer time: distracted by his horses from performing the mid-afternoon prayer before the sun sets, he slaughters his horses in an offering to God, who 'rewards' him for this sacrifice thereby again, presumably, indicating his approval. ${ }^{25}$ This technique of communicating with God is familiar from, for instance, the story of Cain and Abel as

\footnotetext{
${ }^{18}$ See al-Tha 'labī, Qiṣaṣ al-anbiyā', p. 294 citing Muhammad b. Ka'b al-Qaraẓi (cf. Brinner, 'Arā'is al-majālis, p. 493).

${ }^{19}$ See al-Tha'labī, Qișaṣ al-anbiyā', p. 310 citing an anonymous account (cf. Brinner, 'Arā'is almajālis, p. 519).

${ }^{20}$ See al-Tha'labī, Qișaș al-anbiyā', p. 323 citing a composite account on the authority of Muhammad

b. Ishạāq (cf. Brinner, 'Arā'is al-majālis, p. 539).

${ }^{21}$ See al-Tha'labī, Qișaș al-anbiyā', p. 327 citing a composite account including Ibn 'Abbās (cf. Brinner, 'Arā'is al-majālis, p. 545. See my review of this work in Journal of Qur'anic Studies 6:2 (2004), pp. 74-8 for a discussion of Brinner's (mis-)translation of this passage).

${ }^{22}$ See al-Tha 'labī, Qiṣaș al-anbiyā', p. 319 citing Muhammad b. al-Munkadir (cf. Brinner, 'Arā'is almajālis, p. 533).

${ }^{23}$ See al-Tha 'labī, Qiṣaṣ al-anbiyā', p. 317 citing an anonymous account (cf. Brinner, 'Arā'is almajālis, p. 530).

${ }^{24}$ See al-Tha 'labī, Qișaș al-anbiyā', p. 310 citing an anonymous account (cf. Brinner, 'Arā'is almajālis, p. 519).

${ }^{25}$ See al-Tha'labī, Qiṣaṣ al-anbiyā', p. 302 citing al-Ḥasan (cf. Brinner, 'Arā'is al-majālis, p. 506). See A.H. Johns, 'Solomon and the Horses: The Theology and Exegesis of a Koranic Story, Sura 38 (Sad): 30-33', MIDEO 23 (1997), pp. 259-282, for a discussion of this episode.
} 
given in Q. 5:27, ${ }^{26}$ although it is far from the direct speech with God enjoyed by David and many other prophets.

Moreover God does not only communicate with His prophets directly: they also interact via angelic messengers. Thus David wonders how God is able to hear him over the sound of nature, and Gabriel descends in order to illustrate to him how God hears all of His creatures; ${ }^{27}$ God sends an angel to alert David that he feeds his family out of funds from the public treasury; ${ }^{28}$ Gabriel brings a message from God warning David not to marvel at his own worship, ${ }^{29}$ God sends two angels to show David that he has wronged Uriah; ${ }^{30}$ Gabriel tells David that God has forgiven him for this, David asks whether God has absolved him of the resultant bloodwit, Gabriel offers to ask God about this aspect of the issue, David agrees, and Gabriel returns with God's answer; ${ }^{31}$ Gabriel raises David's head after God forgives him his $\sin ;{ }^{32}$ the angel of death comes to take David's soul and David converses with him about his purpose and the alleged lack of warning of his coming, issues duly answered by the angel. ${ }^{33}$

In the case of Solomon, meanwhile, God orders the angels to turn the sun back for Solomon; ${ }^{34}$ an angel delivers a blow to any demon that defies Solomon's command; ${ }^{35}$ Gabriel tells Solomon what is inside the Queen of Sheba's sealed casket; ${ }^{36}$ Gabriel or

\footnotetext{
${ }^{26}$ [Prophet], tell them the truth about the story of Adam's two sons: each of them offered a sacrifice, and it was accepted from one and not the other. One said, 'I will kill you,' but the other said, 'God only accepts the sacrifice of those who are mindful of Him.'

${ }^{27}$ See al-Tha'labī, Qiṣaș al-anbiyā', p. 276 on no named authority (cf. Brinner, 'Arā'is al-majālis, p. 464).

${ }^{28}$ See al-Tha 'labī, Qiṣaș al-anbiyā', p. 278 on no named authority (cf. Brinner, 'Arā'is al-majālis, p. 467).

${ }^{29}$ See al-Tha 'labī, Qiṣaș al-anbiyā', p. 280 citing Abū Bakr b. Muḥammad b. 'Umar al-Warrāq (cf. Brinner, 'Arā'is al-majālis, p. 470).

${ }^{30}$ See al-Tha 'labī, Qiṣaṣ al-anbiyā', p. 280 citing Abū Bakr b. Muḥammad b. 'Umar al-Warrāq (cf. Brinner, 'Arā'is al-majālis, p. 471).

${ }^{31}$ See al-Tha'labī, Qiṣaș al-anbiyā', p. 282 citing a Hadīth (cf. Brinner, 'Arā'is al-majālis, p. 473).

${ }^{32}$ See al-Tha 'labī, Qiṣaș al-anbiyà', p. 284 citing Ka‘b al-Aḥbār and Wahb b. Munabbih (cf. Brinner, 'Arā'is al-majālis, p. 475).

${ }^{33}$ See al-Tha'labī, Qiṣaṣ al-anbiyā', p. 292 citing Abū 'Amr al-Fārābī (cf. Brinner, 'Arā'is al-majālis, pp. 489-90).

${ }^{34}$ See al-Tha 'labī, Qiṣaș al-anbiyā', p. 303 citing 'Alī b. Abī Ṭālib (cf. Brinner, 'Arā'is al-majālis, p. 507).

${ }^{35}$ See al-Tha 'labī, Qișaș al-anbiyā', p. 304 on no named authority (cf. Brinner, 'Arā'is al-majālis, p. 509).

${ }^{36}$ See al-Tha 'labī, Qiṣaṣ al-anbiyā', p. 317 citing an anonymous source (cf. Brinner, 'Arā'is almajālis, p. 530).
} 
another angel promises to bring the Queen of Sheba's throne to Solomon; ${ }^{37}$ in another account God sends the angels to bring the throne to Solomon; ${ }^{38}$ Gabriel comes to Solomon with a message from God during his meeting with the Queen of Sheba and they converse, ${ }^{39}$ Gabriel gives Solomon the seal ring that contains his sovereignty; ${ }^{40}$ the Angel of Death comes to warn Solomon of his incipient death, or, in another account, the Angel of Death enters the palace, greets Solomon, and the pair converse about Solomon's desire to enjoy a care-free day, after which Solomon requests that his soul be taken. ${ }^{41}$ Again, however, there is a disparity in the nature of the dialogue between David and God's angels, and Solomon and these messengers: although both prophets enjoy a conversation with the Angel of Death immediately prior to their souls being taken, the only other instance in which Solomon is quoted as having a two-way conversation with an angel is when Gabriel descends with a message for the prophet during his encounter with the Queen of Sheba; contrast this with the much more interactive nature of David's dealings with the angels.

It can be argued that God's presence and esteem are likewise expressed through His bestowal of gifts upon His prophets. Accordingly, we are told that David is given the psalms, a beautiful voice, good intonation, and exquisite melodies, ${ }^{42}$ the subservience of mountains and birds, ${ }^{43}$ wisdom and judicial insight, ${ }^{44}$ a magical chain that distinguishes true from false, ${ }^{45}$ strength of worship, intensity of effort (for instance in

\footnotetext{
${ }^{37}$ See al-Tha 'labī, Qiṣaș al-anbiyā', p. 319 citing anonymous sources (cf. Brinner, 'Arā'is al-majālis, p. 532).

${ }^{38}$ See al-Tha 'labī, Qiṣaș al-anbiyā', p. 319 citing Ibn 'Abbās (cf. Brinner, 'Arā'is al-majālis, p. 532).

${ }^{39}$ See al-Tha 'labī, Qișaș al-anbiyā', p. 321 citing Wahb b. Munabbih (cf. Brinner, 'Arā'is al-majālis, p. 535).

${ }^{40}$ See al-Tha 'labī, Qișaṣ al-anbiyā', p. 323 on no named authority (cf. Brinner, 'Arā'is al-majālis, p. 539).

${ }^{41}$ See al-Tha'labī, Qișaș al-anbiyā', p. 327 citing 'Abd al-Raḥmān b. Zayd (cf. Brinner, 'Arā'is almajālis, p. 545), and al-Tha 'labī, Qișaș al-anbiyā', p. 327 citing unnamed sources (cf. Brinner, 'Arā'is al-majālis, p. 546).

${ }^{42}$ See al-Tha 'labī, Qiṣaṣ al-anbiyā', p. 275 citing no named source alongside Q. 4:163, To David We gave the book [of Psalms] (cf. Brinner, 'Arā'is al-majālis, p. 462).

${ }^{43}$ See al-Tha 'labī, Qiṣaș al-anbiyā', p. 276 citing no named source alongside Q. 34:10, We graced David with Our favour. We said, 'You mountains, echo God's praises together with him, and you birds, too.' We softened iron for him, and Q. 21:79, We made the mountains and the birds celebrate Our praises with David (cf. Brinner, 'Arā'is al-majālis, p. 463).

${ }^{44}$ See al-Tha'labī, Qișaș al-anbiyā', p. 276 on no named authority (cf. Brinner, 'Arā'is al-majālis, pp. 464-5).

${ }^{45}$ See al-Tha'labī, Qiṣaṣ al-anbiyā', p. 277 on no named authority (cf. Brinner, 'Arā'is al-majālis, p. 465).
} 
fasting), ${ }^{46}$ strength of sovereignty, ${ }^{47}$ bravery, ${ }^{48}$ the softening of iron, ${ }^{49}$ and a book of questions to ascertain whether Solomon should succeed his father. ${ }^{50}$ Solomon is meanwhile granted dominion and wisdom, ${ }^{51}$ unprecedented special characteristics, ${ }^{52}$ the subjugation of the wind, ${ }^{53}$ the ability to understand the speech of the birds and the ants,${ }^{54}$ perfect Arab horses brought out from the sea, ${ }^{55}$ a spring of molten brass, ${ }^{56}$ the subjection of the jinn, mankind, birds, beasts and demons, ${ }^{57}$ and the task of completing the Temple, denied to David. ${ }^{58}$ Here therefore it can be argued that it is Solomon who seems to be singled out by God for special attention, for although David's gifts are indeed delightful, they do not match the power and grandeur of all that God bestows upon Solomon; it seems clear therefore that while Solomon does not appear to enjoy the close relationship with God his father was privileged to experience, this is by no means a sign of God's displeasure, merely a different way of interacting with each of the pair.

The question remains, however, of whether these contrasting patterns of divine communication affect each prophet's apparent understanding of, and interaction with, God and whether we can, in turn, draw conclusions from this regarding God's

\footnotetext{
${ }^{46}$ See al-Tha 'labī, Qiṣaș al-anbiyā', p. 277 citing no named source alongside Q. 38:17, Remember Our servant David, a man of strength who always turned to Us (cf. Brinner, 'Arā'is al-majālis, p. 466).

${ }^{47}$ See al-Tha'labī, Qișas al-anbiyā', p. 278 citing no named source alongside Q. 38:20, We strengthened his kingdom (cf. Brinner, 'Arā'is al-majālis, p. 466).

${ }^{48}$ See al-Tha'labī, Qiṣaș al-anbiyā', p. 278 on no named authority (cf. Brinner, 'Arā'is al-majālis, p. 467).

${ }^{49}$ See al-Tha 'labī, Qișaș al-anbiyā', pp. 278-9 citing no named source alongside Q. 34:10-11 We softened iron for him, saying 'Make coats of chain mail and measure the links well' (cf. Brinner, 'Arā'is al-majālis, pp. 467-8), and alluded to (though not discussed) on p. 276 through al-Tha'labī's citation of Q. 34:10 (cf. Brinner, 'Arā'is al-majālis, p. 464).

${ }^{50}$ See al-Tha'labī, Qișaș al-anbiyā', p. 290 citing Abū Hurayra (cf. Brinner, 'Arā'is al-majālis, p. 486).

${ }^{51}$ See al-Tha'labī, Qiṣaș al-anbiyā', p. 292 citing Muqātil (cf. Brinner, 'Arā'is al-majālis, p. 490).

${ }^{52}$ See al-Tha 'labī, Qiṣaṣ al-anbiyā', p. 293 on no named authority (cf. Brinner, 'Arā'is al-majālis, p. 491).

${ }^{53}$ See al-Tha 'labī, Qișas al-anbiyā', p. 293 citing no named source alongside Q. 38:36, So We gave him power over the wind, which at his request ran gently wherever he willed (cf. Brinner, 'Arä'is almajālis, p. 491).

${ }^{54}$ See al-Tha'labī, Qișaș al-anbiyā', p. 294 citing no named source alongside Q. 27:16, People, we have been taught the speech of birds (cf. Brinner, 'Arā'is al-majālis, p. 493).

${ }^{55}$ See al-Tha'labī, Qiṣaṣ al-anbiyā', p. 302 on no named authority (cf. Brinner, 'Arā'is al-majālis, p. 506).

${ }^{56}$ See al-Tha 'labī, Qiṣaș al-anbiyā', p. 304 citing no named source alongside Q. 34:12, We made a fountain of molten brass flow for him (cf. Brinner, 'Arā'is al-majālis, p. 508).

${ }^{57}$ See al-Tha 'labī, Qișaș al-anbiyā', p. 304 citing no named source (cf. Brinner, 'Arā'is al-majālis, pp. 508-9).

${ }^{58}$ See al-Tha 'labī, Qișaș al-anbiyā', p. 308 citing an anonymous source (cf. Brinner, 'Arā'is al-majālis, p. 516). For a discussion of David's 'apparent subordination' to Solomon see Hamid Algar, 'Q. 21:78-

9: A Qur'anic Basis for Ijtihad?', Journal of Qur'anic Studies 4.2 (2002), pp. 1-22.
} 
perceived authority in the narrative. Let us turn to evidence of each prophet's construction of God within the two texts. In addition to the God we perceive through direct dialogue, David explicitly mentions God in the following instances: within the Saul story, he tells his father how he was praising God as he walked through the mountains, and the mountains started praising God alongside him $;^{59}$ he rejects Saul's offer of weapons with which to fight Goliath, saying that victory is rather in God's hands; ${ }^{60}$ he tells Goliath that God will 'scatter his flesh between the beasts and the birds in the sky', and places the rocks that will kill Goliath in his slingshot saying 'In the name of God'; ${ }^{61}$ when Saul tries to kill David, he says, 'God forbid that I should fear anything other than God, or take refuge in anything other than Him. He is the only one capable of repelling evil,' and cites the Torah in support of retaliation; ${ }^{62}$ when David flees Saul and goes to the mountains, he dedicates himself to the service of God there. ${ }^{63}$ Within the actual David story, we are told that the prophet was 'repentant, glorifying God and obedient', and his rigorous fasting habits are described; ${ }^{64}$ later we are told that he spent one day in three 'serving his Lord and reciting the Scriptures'; ${ }^{65}$ when he sends Uriah to the front, we are told that this is a position it was not lawful to abandon until 'God granted victory or made him a martyr'; ${ }^{66}$ in his conversation with Gabriel, David is sure of God's forgiveness and justice, but sees this as applying also to God's granting of recompense to Uriah for David's actions toward him; ${ }^{67}$ finally, David tells Solomon that God has sent a book of questions to determine his successor and told him to ask him them, then announces to the people that God has commanded that Solomon be made his successor; ${ }^{68}$ he

\footnotetext{
${ }^{59}$ See al-Tha'labī, Qiṣaṣ al-anbiyā', p. 270 citing a composite account (cf. Brinner, 'Arā'is al-majālis, p. 453).

${ }^{60}$ See al-Tha 'labī, Qiṣaș al-anbiyā', p. 271 citing a composite account (cf. Brinner, 'Arā'is al-majālis, p. 455).

${ }^{61}$ See al-Tha'labī, Qișaṣ al-anbiyā', p. 271 citing a composite account (cf. Brinner, 'Arā'is al-majālis, p. 456).

${ }^{62}$ See al-Tha 'labī, Qiṣaṣ al-anbiyā', p. 272 citing Wahb b. Munabbih (cf. Brinner, 'Arā'is al-majālis, pp. 457-8).

${ }^{63}$ See al-Tha'labī, Qiṣaṣ al-anbiyā', p. 273 citing Wahb b. Munabbih (cf. Brinner, 'Arā'is al-majālis, p. 459).

${ }^{64}$ See al-Tha 'labī, Qișaș al-anbiyā', p. 277 on no named authority, in reference to Q. 38:17, Remember Our servant David, a man of strength who always turned to Us (cf. Brinner, 'Arā'is al-majālis, p. 466).

${ }^{65}$ See al-Tha'labī, Qișas al-anbiȳ̄', p. 279 citing a composite account on the authority of al-Suddī, alKalbī and Muqātil (cf. Brinner, 'Arā'is al-majālis, p. 468).

${ }^{66}$ See al-Tha'labī, Qișaș al-anbiyā', p. 280 citing al-Suddī (cf. Brinner, 'Arā'is al-majālis, p. 469).

${ }^{67}$ See al-Tha 'labī, Qișaș al-anbiyā', p. 282 citing a Hadīth (cf. Brinner, 'Arā'is al-majālis, p. 473).

${ }^{68}$ See al-Tha'labī, Qișaș al-anbiyā', p. 290 citing Abū Hurayra (cf. Brinner, 'Arā'is al-majālis, pp. 486-7).
} 
subsequently tells Solomon to take strength in God, obey Him, and spread His mercy. $^{69}$

Solomon, meanwhile, explicitly mentions God when David presents him with the book of questions, saying 'I cannot succeed without God's help' $;^{70}$ he talks of God to a ploughman, telling him that a divinely-accepted statement of his (the ploughman's) praise is worth more than all that has been given to the family of David; ${ }^{71}$ he explains to his courtiers that the call of the shrike invites sinners to beg pardon of God, while various other birds (and the frog) speak out in praise of Him, ${ }^{72}$ the swift asks God to help those who go astray, the lark calls on Him to curse those who hate the family of Muhammad, ${ }^{73}$ and the ant warns all to fear God in public and in private, be frugal in poverty and in wealth, and act justly in contentment and in anger; ${ }^{74}$ Solomon argues at length with the phoenix about the nature of fate and God's decree, stating that 'God does not give His servants any will of their own'; ${ }^{75}$ he tells the Queen of Sheba's messengers that he has no need of the world, for God has already placed it in his hands, and given him prophethood and wisdom besides $;^{76}$ when one of the Israelites points out to him that, as God's prophet, God will answer his request for the Queen of Sheba's throne, the prophet realises that this is indeed the case and prays for the throne; ${ }^{77}$ he orders the Queen of Sheba to accept a husband, stating that it is not appropriate for her to forbid what God has permitted. ${ }^{78}$ Solomon also tells his wife not to grieve for the loss of her father or her homeland, as God has given her better in

\footnotetext{
${ }^{69}$ See al-Tha'labī, Qiṣaș al-anbiyā', p. 291 citing Wahb b. Munabbih (cf. Brinner, 'Arā'is al-majālis, p. 488).

${ }^{70}$ See al-Tha'labī, Qiṣaș al-anbiyā', p. 290 citing Abū Hurayra and Q. 11:88 (cf. Brinner, 'Arā'is almajālis, p. 486).

${ }^{71}$ See al-Tha 'labī, Qiṣaș al-anbiyā', p. 293 citing the father of Wahb b. Munabbih (cf. Brinner, 'Arā'is al-majālis, p. 492).

${ }^{72}$ See al-Tha 'labī, Qișaș al-anbiyā', p. 294 citing, variously, Ka‘b al-Aḥbār and Makhūl (cf. Brinner, 'Arā'is al-majālis, pp. 493-4).

${ }^{73}$ For both these statements see al-Tha'labī, Qișaș al-anbiyā', p. 295 citing al-Husayn b. 'Alī (cf. Brinner, 'Arā'is al-majālis, p. 494).

${ }^{74}$ See al-Tha 'labī, Qișaṣ al-anbiyā', p. 295 citing an unnamed source (cf. Brinner, 'Arā'is al-majālis, p. 495).

${ }^{75}$ See al-Tha 'labī, Qiṣaṣ al-anbiyā', p. 301 citing Muhammad b. Ja'far al-ṣādiq (cf. Brinner, 'Arā'is almajālis, p. 505).

${ }^{76}$ See al-Tha'labī, Qiṣaș al-anbiyā', p. 318 citing various unnamed sources and Wahb b. Munabbih (cf. Brinner, 'Arā'is al-majālis, p. 530).

${ }^{77}$ See al-Tha 'labī, Qiṣaș al-anbiyā', p. 319 citing Muhammad b. al-Munkadir (cf. Brinner, 'Arā'is almajālis, p. 533).

${ }^{78}$ See al-Tha'labī, Qișaș al-anbiyā', p. 321 citing Wahb b. Munabbih (cf. Brinner, 'Arā'is al-majālis, p. 536).
} 
return: Solomon's kingdom, and Islam. ${ }^{79}$ Finally, he says to his friends that God has given him great sovereignty, but that he has never spent an untroubled day. ${ }^{80}$ If we consider these statements, and contrast them to the utterances within the David narrative, the pervading impression is of a much stronger sense of God, both as an individual and as a presence, within the Solomon narrative.

God's presence in the Solomon story can also be read in the prophet's reaction to the perceived threat of God's anger: the prophet flicks away an ant, who rebukes him, saying 'Don't you know that I am the slavegirl of Him whose servant you are?', and Solomon swoons, then asks the ant that he be absolved of his action; ${ }^{81}$ Solomon swears that he will kill or severely punish the hoopoe for its absence from his court, but the hoopoe reminds him that he stands before God and Solomon 'trembles and forgives him'; ${ }^{82}$ the reason for Solomon's extreme anger at the hoopoe is the fear of there being a delay to his prayer time because the bird is not there to source water for him to wash before prayer; ${ }^{83}$ in some accounts Solomon slaughters his horses in sacrifice to God after they cause him to miss the mid-afternoon prayer. ${ }^{84}$ Another episode of note could arguably be the occasion where the Queen of Sheba asks Solomon to explain to her how God exists, and the prophet falls down from his throne in prayer. Gabriel wipes the memory of all those present, with the possible exception of Solomon himself, clean of the incident. ${ }^{85}$

There is nothing comparable to any of these episodes in the David story: he seems quite confident, for instance, in the appropriateness and acceptability of his prayer habits (indeed, he has the reassurance of Gabriel's demonstration to him of how even

\footnotetext{
${ }^{79}$ See al-Tha'labī, Qișaș al-anbiyā', p. 322 citing a composite account on the authority of Muhammad b. Ishāàq (cf. Brinner, 'Arā'is al-majālis, p. 538).

${ }^{80}$ See al-Tha 'labī, Qiṣaṣ al-anbiyā', p. 327 citing unnamed sources (cf. Brinner, 'Arā'is al-majālis, pp. 545-6).

${ }^{81}$ See al-Tha 'labī, Qiṣaṣ al-anbiyā', p. 296 on no named authority (cf. Brinner, 'Arā'is al-majālis, pp. 495-6).

${ }^{82}$ See al-Tha 'labī, Qișaṣ al-anbiyā', p. 312 citing no named source (cf. Brinner, 'Arā'is al-majālis, p. 522).

${ }^{83}$ See al-Tha 'labī, Qiṣaṣ al-anbiyā', p. 312 on no named authority (cf. Brinner, 'Arā'is al-majālis, p. 521).

${ }^{84}$ See al-Tha 'labī, Qișaș al-anbiyā', p. 302 citing anonymous sources (cf. Brinner, 'Arā'is al-majālis, p. 506). Again, see Johns, 'Solomon and the Horses: The Theology and Exegesis of a Koranic Story, Sura 38 (Sad): 30-33', for a discussion of this episode.

${ }^{85}$ See al-Tha'labī, Qișaș al-anbiyā', p. 321 citing Wahb b. Munabbih (cf. Brinner, 'Arā'is al-majālis, p. 535).
} 
the quietest prayers are heard, and the comfort provided by hearing the mountains worship alongside him), and although he weeps long and hard over the realisation of the part he played in the Bathsheba situation, God would appear to be at pains to reassure His prophet that He has indeed forgiven him. ${ }^{86}$ Therefore, for all that it says at one point in al-Tha'labì's text that there is nothing wrong with David after his sin but 'his shame and fear of God', ${ }^{87}$ it cannot be argued that it is fear of God's reaction per se that causes him to behave in this way; moreover, we are told in one anecdote that when David remembered God's punishment, his limbs would grow limp, but when he subsequently recalled His mercy, they would return to their normal state. ${ }^{88}$ David's reaction to the possibility of having maybe displeased his Lord is very different to Solomon's. The God we see constructed in David's incidental comments is also different to the God we perceive in the Solomon narrative: where Solomon mentions, and questions, the value of the gifts that have been bestowed upon him, in terms of them granting him salvation, and warns that God should be praised, feared, and supplicated, David's references never exceed the impersonal and commonplace. That the mystery of the divine makes the divine appear more forceful is often posited as a truism. This is amply demonstrated in al-Tha 'labī's narrative. Although Solomon is, like his father before him, liberally bestowed with gifts, and indeed has the power to bestow livelihoods in his turn on the tree-worm and the white worm, he does not appear to communicate with God, either directly or via angelic messenger. He rarely addresses God in direct speech, and, when he does so, God never replies. We can argue that it is in compensation for these absences that we can perceive a pervading sense in the tale of God's silent presence: in the shape of the grandeur of His gifts to Solomon, and in the voices of the birds and the frogs, speaking of His majesty and advising regarding His might. I would also argue that it is in consequence to these absences that we perceive a sense of uncertainty in Solomon's dealings with God; the verbally-communicated-with David seems more self-assured in this respect. Where do trust, familiarity, our need for dialogue, and our perception of, or construction of, power coincide?

\footnotetext{
${ }^{86}$ See al-Tha'labī, Qișaș al-anbiyā', p. 282 citing a Hadīth, and p. 284 citing Wahb b. Munabbih, p. (cf. Brinner, 'Arā'is al-majālis, p.,). See also M.O. Klar, Interpreting al-Tha 'labī's Tales of the Prophets: Temptation, Responsibility and Loss, RoutledgeCurzon, 2009, Chapter 6, and A.H. Johns, 'David and Bathsheba: A Case-study in Qur'anic Exegesis', MIDEO 19 (1989), pp. 225-266.

${ }^{87}$ See al-Tha'labī, Qișaș al-anbiyā', p. 286 citing a Hadīth (cf. Brinner, 'Arā'is al-majālis, p. 479).

${ }^{88}$ See al-Tha'labī, Qișaș al-anbiyā', p. 286 citing Thābit (cf. Brinner, 'Arā' is al-majālis, p. 479).
} 
The final question that remains is the extent to which these two patterns of human divine communication and perceived divine authority outlined above are reflected in the Qur'anic passages per se. If we return to the narratives surrounding the two Qur' anic pericopes in question, we see that although both describe episodes in each prophet's life where he was tried by God, repented, and was given a subsequent reward, in David's case, this information is augmented by a description of the nature of David's repentance (he fell down on his knees, and repented), and followed by a reminder to David that his majesty brings with it the responsibility to judge fairly between people, and he should not give in to his own desires, verse 26: David, We have given you mastery over the land. Judge fairly between people. Do not follow your desires, lest they divert you from God's path. Solomon's Qur'anic pericope includes the words of Solomon's prayer of repentance, Lord, forgive me! Grant me such power as no one after me will have - You are the Most Generous Provider, and, in verses 36-39, a list of God's gifts to His prophet, So We gave him power over the wind, which at his request ran gently wherever he willed, and the jinn - every kind of builder and diver and others chained in fetters. This is Our gift, so give or withhold as you wish without account. The tone of the historiographical narrative, therefore, can be seen to echo the Qur'anic passages about which such narratives are built: David receives words of counsel from his Lord, yet despite the fact that Solomon directly addresses God, he is rewarded not with counsel but with gifts of sovereignty and power.

The context for each Qur'anic repentance narrative is provided by the immediately preceding Qur'anic verses: for David, the prophet's ruling in the case of two litigants, seen as an allegory for David himself and Uriah, whose wife Bathsheba David subsequently married; in Solomon's by the parade-ground incident, conflictingly interpreted as referring to Solomon's declaring his love of his horses to be part of his worshipping God, and stroking them as a result, or, as mentioned above, Solomon's being distracted from prayer by a parade of his horses and slaughtering them as a result. The historiographical tradition expounds on these two passages by providing reasons for why Bathsheba was placed in David's way; for Solomon, however, alTha'labī gives several alternative contexts for Solomon's trial and subsequent 
repentance: inter alia, various sins connected to marriage, including the sanctioned or unsanctioned worship of an idol by the prophet's wife, the horses incident mentioned above, or Solomon attempting to cheat death on his small child's behalf by handing the child over to the clouds for safe-keeping. Solomon's trial per se is then defined as being the skeleton on the throne mentioned in the Qur'anic pericope: either the body of Solomon's son cast down onto the throne, or the replacement of Solomon on his throne, by his vizier, or by a demon who assumes the prophet's form. ${ }^{89}$ It would therefore appear that while al-Tha' labī and his sources are comfortable, and confident, in ascribing David's trial to the incident with Bathsheba, there is some doubt over the identification of Solomon's trial, both insofar as we are unsure of the cause of it, and insofar as we are unsure of its manifestation. What I would like to propose is that one of the areas in which this lack of certainty manifests itself is in the sense of insecurity we perceive in Solomon's perception of and dealings with God. Here we turn again to the interaction between our need for secure knowledge, and our perception of power. If the narrative itself cannot be confident of how the prophet disobeyed God's laws, or of what the resultant punishment may have been, how can we expect the Solomon who is a construct of this very narrative to act in a confident manner? In my closing statement, therefore, I would say that although the Qur'an may not explicitly dictate the nature of the human divine power paradigm in these two cases, it definitely informs the terms by which these relationships are constructed.

\footnotetext{
${ }^{89}$ See M.O. Klar, 'And We cast upon the throne a mere body: A Historiographical Reading of Q. 38:34', Journal of Qur'anic Studies 6.1 (2004), pp. 103-126, for a discussion of these narratives.
} 